Рад примљен: 26. 4. 2017.

Рад прихваћен: 10. 9. 2017.

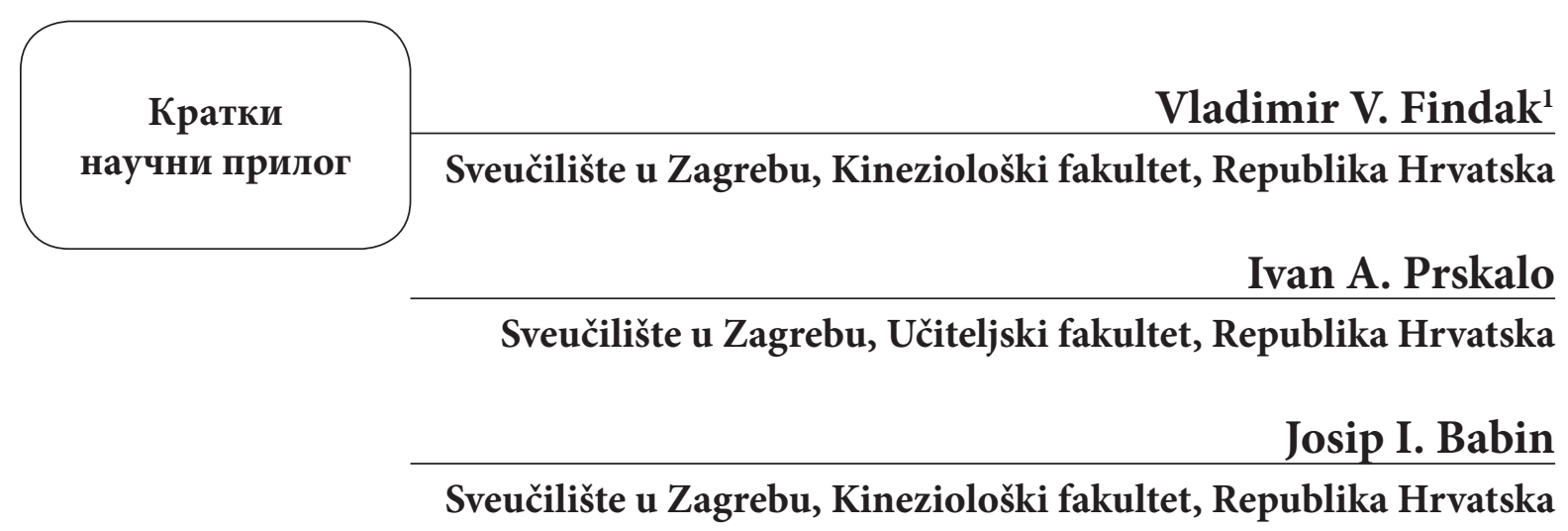

\title{
Kvaliteta kineziološke edukacije - uvjet opstanka
}

\begin{abstract}
Rezime: Značajno obilježje vremena u kojem živimo su promjene. Kako se te promjene odražavaju na cjelokupnu populaciju, odgovor na njih treba biti primjeren. Pozitivan utjecaj tjelesnog vježbanja na antropološki status je teško usporediv s bilo kojom ljudskom aktivnošću, a ne treba zanemariti vezu tjelesnog vježbanja, motoričkih i funkcionalnih sposobnosti i zdravstvenog statusa, uvjeta kvalitetnog življenja. Uvjet za kvalitetu u ovom prevažnom području su primijenjena znanstvena istraživanja $i$ njihova dosljedna primjena u neposrednoj praksi. Pregled iskustava koja doprinose kvaliteti kineziološke edukacije kao uvjeta opstanka pokazuje kako posebnu pažnju treba posvetiti stanju antropoloških obilježja, bitnom preduvjetu individualizacije, ali $i$ posljedici individualnog pristupa njegovoj optimalizaciji. Organizacijski oblici rada u tjelesnom $i$ zdravstvenom odgojno-obrazovnom području te odgovarajuća primjena modaliteta rada prema višestruko potvrđenoj paradigmi također su bitan čimbenik individualizacije, ali i kvalitete rada $u$ kineziološkoj edukaciji. Imajući sve to u vidu, odgovor društva prema sve prisutnijim izazovima koji se nameću suvremenoj civilizaciji mora biti uskladen s dosezima supstratne znanosti kineziologije $i$ njene primijenjene discipline kineziološke metodike, a s obzirom na „ulog", samo najbolji odgovor je dovoljno dobar odgovor.
\end{abstract}

Ključne riječi: kvaliteta, kineziološka edukacija, antropološka obilježja, sat tjelesne $i$ zdravstvene kulture, individualizacija.

1 hssr@zg.ht.hr

Copyright $\odot 2018$ by the authors, licensee Teacher Education Faculty University of Belgrade, SERBIA.

This is an open access article distributed under the terms of the Creative Commons Attribution License (CC BY 4.0) (https://creativecommons.org/licenses/by/4.0/), which permits unrestricted use, distribution, and reproduction in any medium, provided the original paper is accurately cited. 


\section{Uvod}

Značajno obilježje vremena u kojem živimo su promjene. Kako se te promjene odražavaju na cjelokupnu populaciju, odgovor na njih treba biti primjeren i pripremljen s punom odgovornošću koje društvo ima prema svakoj individui. Kako su, prema Rosiću (Rosić, 1999), odgoj i obrazovanje najsloženije i najodgovornije ljudske aktivnosti, a od „svih područja primijenjene kineziologije, kvaliteta rada u kineziološkoj edukaciji ima najveće učinke na cjelokupnu populaciju, jer je ovo područje sveobuhvatno i prati ljudsko biće od predškolske do visokoškolske dobi“ (Prskalo, Babin, 2006: 26), te u skladu s tom mogućnošću i imperativom utjecaja postaje paradigmom optimalnog odgovora na suvremene trendove, posebice one negativne. Pozitivan utjecaj kineziologa i stručno programiranog tjelesnog vježbanja na antropološki status je teško usporediv s bilo kojom ljudskom aktivnošću (Hardman, 2002; Jensen, 2003; Findak i sur., 2003; Findak, Prskalo, 2005; Findak, Neljak, 2006), te ne treba zanemariti vezu tjelesnog vježbanja, motoričkih i funkcionalnih sposobnosti i zdravstvenog statusa, uvjeta kvalitetnog življenja (Vuori, 2004; Warburton et al., 2006; Horst et al., 2007). Uvjet za kvalitetu u ovom prevažnom području su primjena znanstvenih istraživanja koja već jesu na potrebnoj znanstvenoj razini (Findak, Neljak, 2006). S obzirom na dobru znanstvenu utemeljenost, definiranje cilja te izbor sadržaja bitne su pretpostavke uspješnosti sata, temeljnog organizacijskog oblika rada u planu i programu tjelesne i zdravstvene kulture (Findak i sur., 2011). Upravo će od sata ovisiti kvaliteta rada u cjelokupnoj edukaciji, pri čemu se misli i na usmjeravanje učenika na ostale organizacijske oblike rada u tjelesnom i zdravstvenom odgojno-obrazovnom području, odnosno svojevrsnu pripremu za kulturu provedbe cjeloživotnog vježbanja. Na taj način sat tjelesne i zdravstvene kulture postaje ne samo temeljni organizacijski oblik rada već temelj kvalitete u edukaciji.

\section{Organizacijski oblici rada u tjelesnom i zdravstvenom odgojno-obrazovnom području}

„Tjelesno i zdravstveno područje od temeljnoga je značaja za skladan razvoj psihosomatskih osobina učenika, za razvoj njihovih psihičkih osobina i motoričkih sposobnosti, za usavršavanje biotičkih i socijalnih motoričkih znanja te za razvoj temeljnih kompetencija" (Ministarstvo znanosti obrazovanja i športa Republike Hrvatske, 2011: 252). Značaj ovog područja u skladu je s njegovim ciljevima koji se mogu ostvariti primjenom nastavnih, izvannastavnih i izvanškolskih organizacijskih oblika rada u osnovnom i diferenciranom programu (Findak, 1992: 1999), a pri tome se ne smije zanemariti činjenica kako je sat temeljni organizacijski oblik rada u planu i programu tjelesne i zdravstvene kulture koji se sukladno tomu ne može ničim zamijeniti pa niti jednim drugim organizacijskim oblikom rada (Findak i sur., 2011).

Prema preporuci Hrvatske udruge kinezioloških metodičara broj sati tjelesne i zdravstvene kulture bi morao biti znatno veći nego što je to danas, prikazano Slikom 1. Tako bi se upotpunila i ostvarila uloga sata tjelesne i zdravstvene kulture.

Podaci pokazuju (Horgan, 2005) kako nedovoljan broj djece od sedam do osamnaest godina ne ostvaruje preporučeno vrijeme sata tjedno provedenog u vježbanju, i to je više izraženo kod djevojčica (58\%) nego kod dječaka (39\%). Na hrvatskom uzorku djece u primarnoj edukaciji podaci pokazuju uključenost dječaka u izvannastavne aktivnosti samo s $26 \%$, a djevojčica s $18 \%$. S druge strane, uključenost $\mathrm{u}$ izvanškolske aktivnosti je značajno veća, i to $70 \%$ dječaci i $59 \%$ djevojčice, pa se postavlja pitanje koliko je školski sustav u mogućnosti dati optimalan odgovor na postojeće potrebe učenika (Prskalo, 2007). Slika 2 pokazuje uključenost djece, učenika i mladeži u druge organizacijske oblike rada po dobnim skupinama (Prskalo, Babin, 2010: 31). 
Tabela 1. Organizacijski oblici rada u tjelesnom i zdravstvenom odgojno-obrazovnom području s obzirom na obrazovne razine određene prema dobnom kriteriju u Republici Hrvatskoj

(Findak, 1992; 1995; 1999; Prskalo, Babin, 2010).

\begin{tabular}{|c|c|c|c|c|}
\hline Dob & $3-6 \mathrm{~g}$. & $7-10 \mathrm{~g}$. & $11-14 \mathrm{~g}$. & $15-18 \mathrm{~g}$. \\
\hline \multirow[t]{8}{*}{ Osnovni program } & $\begin{array}{l}\text { Sat tjelesne i zdr. } \\
\text { kulture }\end{array}$ & $\begin{array}{l}\text { Sat tjelesne i zdr. } \\
\text { kulture }\end{array}$ & $\begin{array}{l}\text { Sat tjelesne i zdr. } \\
\text { kulture }\end{array}$ & Sat tjelesne i zdr. kulture \\
\hline & $\begin{array}{l}\text { Sat tjelesne i zdr. kul- } \\
\text { ture po posebnom } \\
\text { programu }\end{array}$ & $\begin{array}{l}\text { Sat tjelesne i zdr. } \\
\text { kulture po posebnom } \\
\text { programu }\end{array}$ & $\begin{array}{l}\text { Sat tjelesne i zdr. } \\
\text { kulture po posebnom } \\
\text { programu }\end{array}$ & $\begin{array}{l}\text { Sat tjelesne i zdr. kulture po } \\
\text { posebnom programu }\end{array}$ \\
\hline & Mikropredah & Natjecanja u razredu & Natjecanja u razredu & Natjecanja u razredu \\
\hline & Makropredah & Priredbe & Priredbe & Priredbe \\
\hline & Šetnje & Izleti & Izleti & Izleti \\
\hline & Izleti & Obuka neplivača & Obuka neplivača & Mikropauze \\
\hline & Priredbe & Logorovanje & Logorovanje & \\
\hline & $\begin{array}{l}\text { Jutarnje tjelesno } \\
\text { vježbanje }\end{array}$ & Mikropauze & Mikropauze & \\
\hline $\begin{array}{l}\text { Diferencirani } \\
\text { program }\end{array}$ & $\begin{array}{l}\text { Zimovanje } \\
\text { Ljetovanje }\end{array}$ & $\begin{array}{l}\text { Zimovanja i } \\
\text { ljetovanja } \\
\text { Izborne aktivnosti }\end{array}$ & $\begin{array}{l}\text { Izborne aktivnosti } \\
\text { Izborni programi } \\
\text { Međurazredna, } \\
\text { školska, općinska, } \\
\text { gradska, državna } \\
\text { natjecanja } \\
\text { Pohodi i planinarenje } \\
\text { Zimovanja i } \\
\text { ljetovanja }\end{array}$ & $\begin{array}{l}\text { Izborni programi } \\
\text { Međurazredna, školska, } \\
\text { općinska, gradska, državna } \\
\text { natjecanja } \\
\text { Pohodi i planinarenje } \\
\text { Zimovanja i ljetovanja } \\
\text { Dopunski programi }\end{array}$ \\
\hline
\end{tabular}

Prema preporuci Hrvatske udruge kinezioloških metodičara broj sati tjelesne i zdravstvene kulture bi morao biti znatno veći nego što je to danas, prikazano Slikom 1. Tako bi se upotpunila i ostvarila uloga sata tjelesne i zdravstvene kulture.

Podaci pokazuju (Horgan, 2005) kako nedovoljan broj djece od sedam do osamnaest godina ne ostvaruje preporučeno vrijeme sata tjedno provedenog u vježbanju, i to je više izraženo kod djevojčica $(58 \%)$ nego kod dječaka (39\%). Na hrvatskom uzorku djece u primarnoj edukaciji podaci pokazuju uključenost dječaka u izvannastavne aktivnosti samo s $26 \%$, a djevojčica s $18 \%$. S druge strane, uključenost u izvanškolske aktivnosti je značajno veća, i to $70 \%$ dječaci i 59\% djevojčice, pa se postavlja pitanje koliko je školski sustav u mogućnosti dati optimalan odgovor na postojeće potrebe učenika (Prskalo, 2007). Slika 2 pokazuje uključenost djece, učenika i mladeži u druge organizacijske oblike rada po dobnim skupinama (Prskalo, Babin, 2010: 31). 
Jasno je kako vrsnoća i dostupnost nastavnim i izvannastavnim oblicima rada predstavljaju pretpostavku kvalitete rada u kineziološkoj edukaciji. Naime, spomenuti životni uvjeti u kojima je prisutnost pretilosti kod najmlađih preduvjet patoloških stanja u budućnosti, srčano-žilne bolesti postaju osnovnim uzrokom smrtnosti (Ćorić, Miler, 2013). S druge strane, tjelovježba se nameće kao faktor redukcije pretilosti (Mišigoj-Duraković i sur., 2003; Flynn et al., 2006). Jasno je kako se ovo treba uzeti u obzir, a kako se vidi, znanstvenici jako dugo upozoravaju na ovu problematiku i na aktualnoj obrazovnoj politici je samo dosljedna primjena spoznaja koje su višestruko potvrđene, a postojeća paradigma se dnevno nadopunjuje. S druge strane, zabrinjava nespremnost školskog sustava da se suoči s izazovom ovih promjena, a to se posebno pokazuje u najmlađim dobnim skupinama, gdje je potreba za kretanjem najveća. Naime, najmlađa dob je dob intenzivnog rasta i razvoja, a kako su intenzivne pozitivne posljedice, tako su intenzivne i one negativne, posebice ako se zanemari kretanje. Još jedna posljedica neuključivanja djece ove dobi u vježbanje je i izostanak navike svakodnevnog vježbanja, što se vrlo lako može odraziti na stil života u zreloj dobi. Posljedice su, kako se vidi iz podataka o uzrocima smrti, „smrtno ozbiljne“.

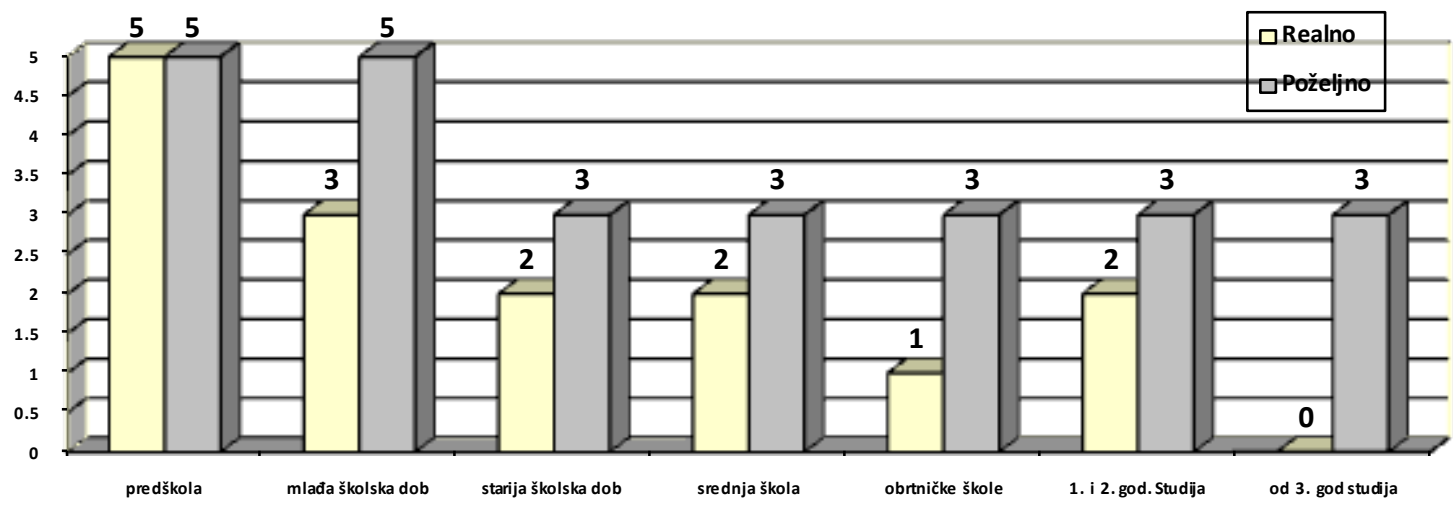

Slika 1. Broj sati kineziološke kulture tjedno na svim razinama obrazovanja i procijenjeni minimalni broj sati da bi se zadovoljio pedagoški standard u ovom području (Prskalo, Babin, 2008: 36).

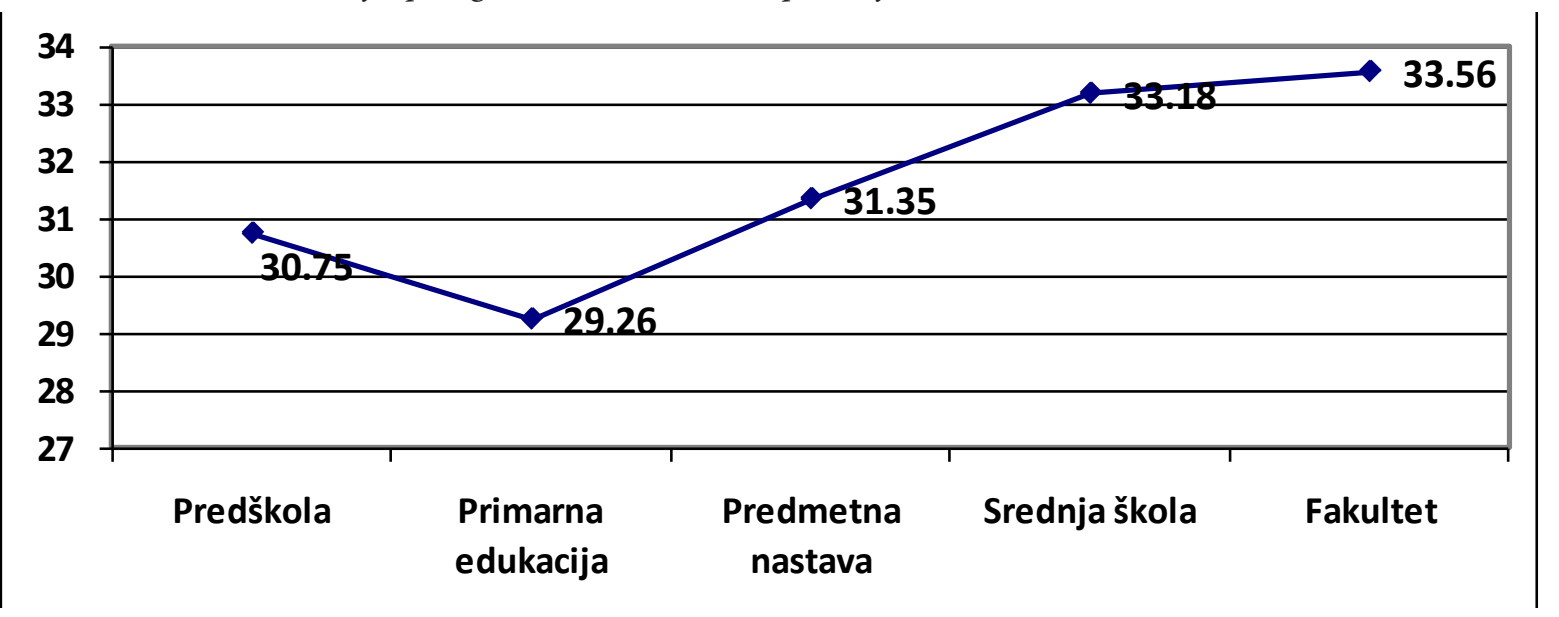

Slika 2. Postotak uključenosti djece, učenika i studenata u druge organizacijske oblike rada u subuzorcima definiranim temeljem razine odgojno-obrazovnog rada (Prskalo, Babin, 2010: 31). 


\section{Modaliteti rada - čimbenik kvalitete u kineziološkoj edukaciji}

„Primijenjena kineziološka disciplina Kineziološka metodika svoje utemeljenje duguje i odgovoru na jedno od ključnih pitanja: „kako vježbati?“. Upravo se pitanje modaliteta vježbanja veže za učin- kovitost i postaje nužno pitanje svih primijenjenih disciplina i jasno je da su modaliteti vježbanja centralno područje koje treba odgovoriti na ključno pitanje „kako vježbati?“ (Prskalo, Sporiš, 2016: 139). Modificirana struktura metoda rada (Prskalo, Sporiš, 2016) prikazana je Slikom 3.

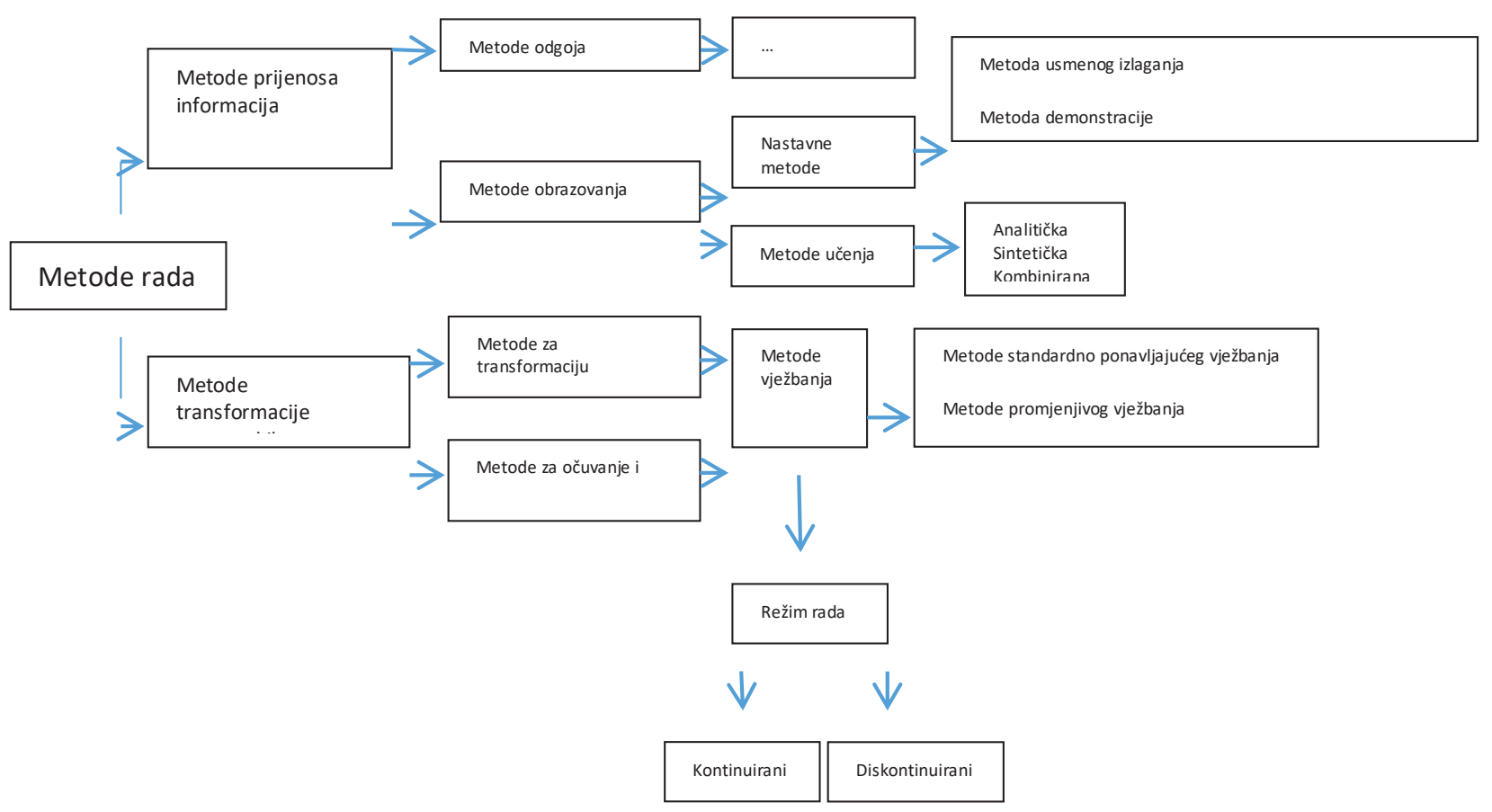

Slika 3. Struktura metoda rada u kineziološkom procesu (modificirano; Mraković, 1997; Findak, 1999; Findak, Mraković, 2003; Milanović, 2010, Prskalo, Sporiš, 2016: 140).

Učinkovitost metoda rada ovisna je o značajkama onoga s kojim se radi, pa je u mlađim dobnim skupinama primjerenija npr. sintetička metoda učenja od analitičke, kako je prikazano u istraživanju na slici 4 (Prskalo i sur., 2003).

Uz metode rada metodički organizacijski oblici rada, uz utjecaj na efektivno vrijeme vježbanja, imaju značajan učinak na intenzifikaciju procesa vježbanja. Najčešći razlog nedovoljne iskorištenosti sata kineziološke kulture je čekanje na red, i to najčešće zbog nedovoljne primjene složenijih metodičkih organizacijskih oblika rada (Findak, 1992), koji praktički eliminiraju ovu pojavu i superiorni su u transformaciji svih triju ciljanih antropološka područja (Bavčević i sur., 2006). Istraživanjem se pokazalo kako je značajno vrijeme pripreme za primjenu zahtjevnijih oblika rada jednako važno kao i njihova primjena, kako je to pokazano Slikom 5 . Naime, pripremljenost za primjenu dopunske vježbe utjecala je na efektivno vrijeme vježbanja, ali i na fiziološko opterećenje na satu tjelesne i zdravstvene kulture. 


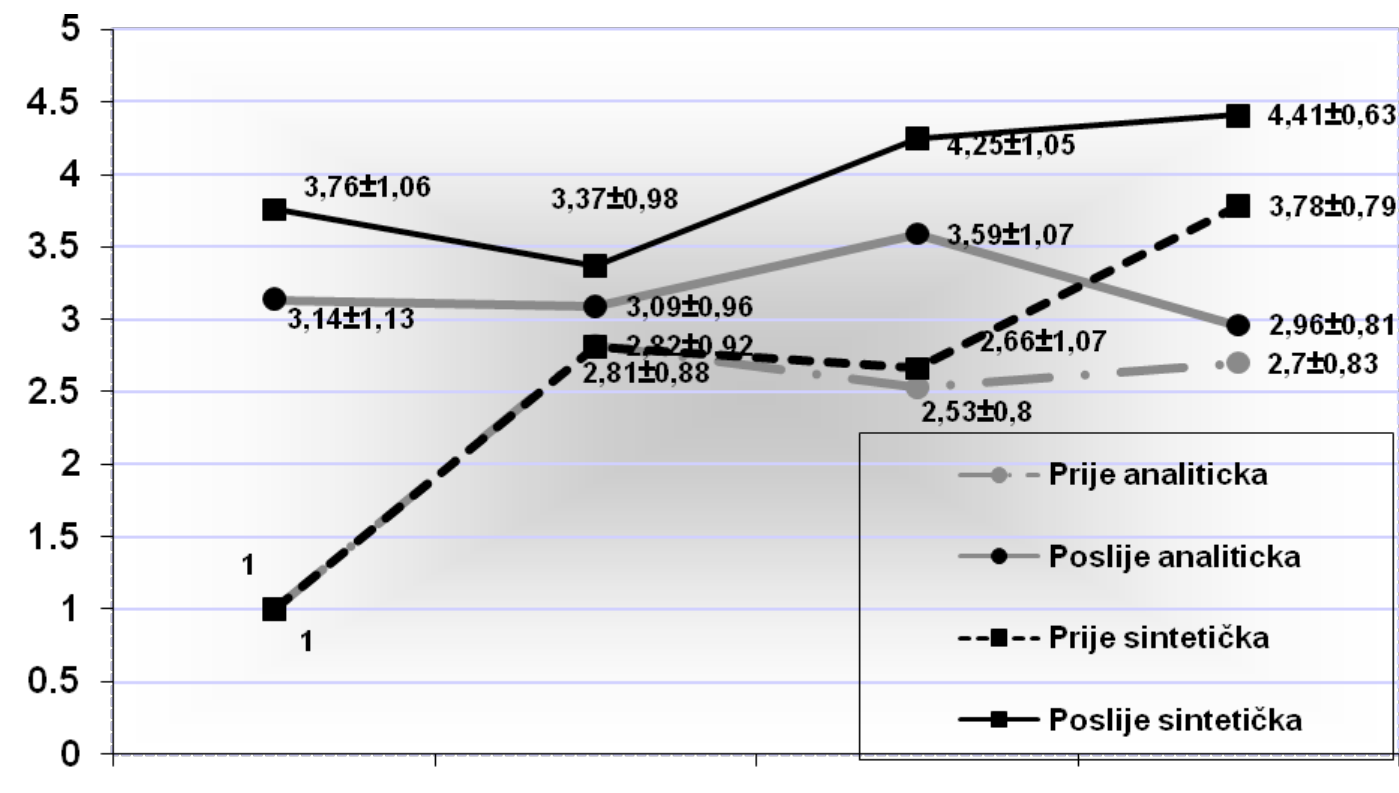
1. razred
2. razred
3. razred
4. razred

Slika 4. Aritmetička sredina ocjena usvojenosti motoričkog gibanja kolut naprijed prije i nakon djelovanja eksperimentalnog faktora - primjene analitičke i sintetičke metode učenja kod djece od 1. do 4. razreda osnovne škole (Prskalo i sur., 2003: 490).

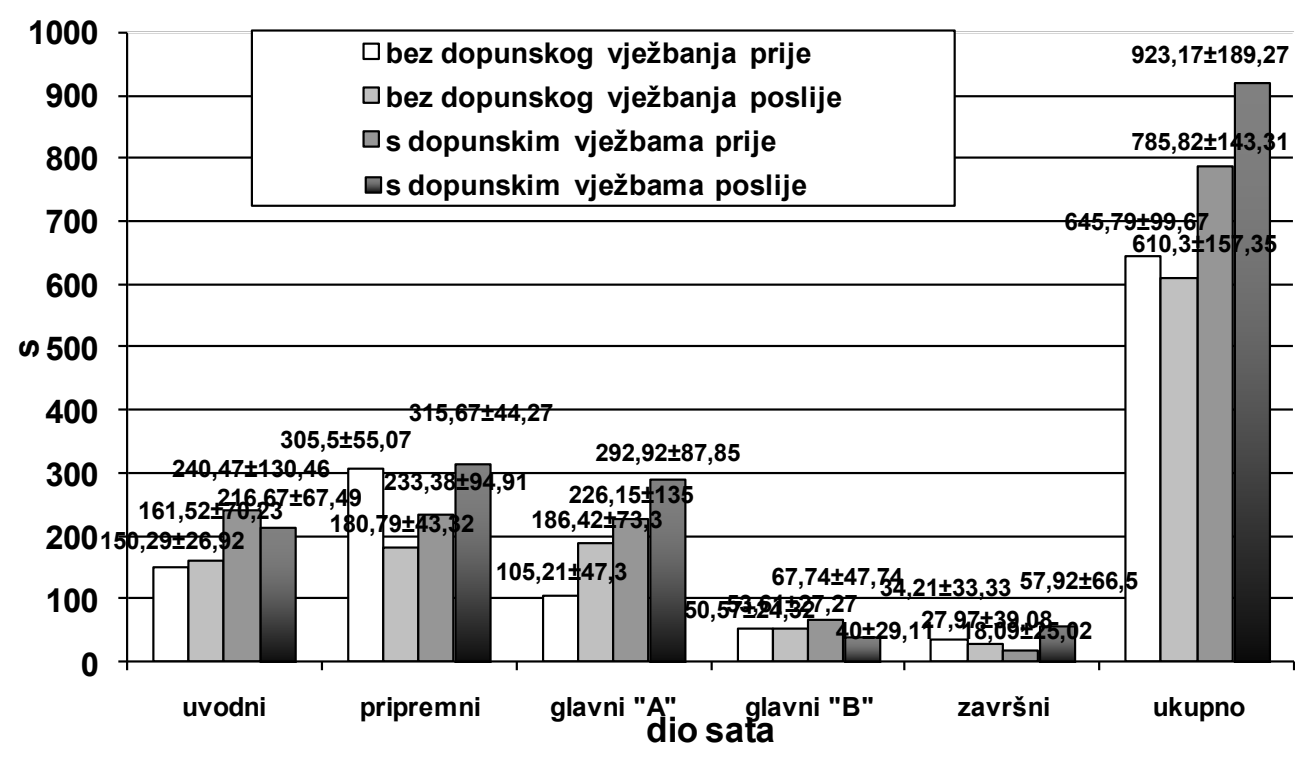

Slika 5. Efektivno vrijeme vježbanja u ovisnosti o primjeni dopunskih vježbi prije i poslije tri mjeseca pripreme za zahtjevnije metodičke organizacijske oblike rada (Findak i sur., 2003). 


\section{Suvremene tehnologije i kvaliteta kineziološke edukacije}

Promjene okruženja u kojem djeca rastu, razvijaju se i odrastaju zahtijevaju drugačiji pristup podučavanju, iako nepotrebno korištenje tehnologije može narušiti temeljnu svrhu kineziološke kulture (Jurak i sur., 2015). Prosječna mjesečna i tjedna primjena novih tehnologija te njihovo poznavanje prikazani su Slikom 6.

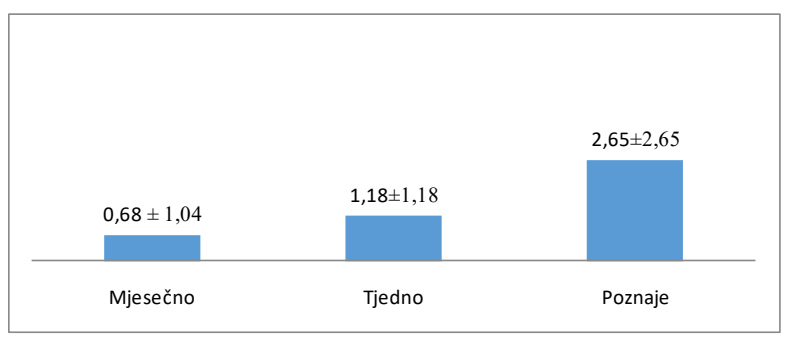

Slika 6. Prosječna mjesečna i tjedna primjena broja novih tehnologija te poznavanje novih tehnologija (Jurak i sur., 2015: 24).

Veliki broj stručnjaka ne primjenjuje nove tehnologije, i to 50\% nikako (Jurak i sur., 2015).

\section{Individualizacija i kvaliteta u edukaciji}

Uspješnost u svakoj ljudskoj djelatnosti ovisi o zadovoljenju autentičnih potreba, interesa i želja, a uz to definicija individualizacije, kao maksimalno približavanje programa vježbanja individualnim obilježjima subjekta $s$ unaprijed definiranim ciljevima, nezamisliva je bez poznavanja antropološkog statusa subjekta (Findak, 1999). Proces vježbanja kao upravljački sustav (Mraković, 1977) nezaobilazan je u definiranju individualiziranog rada, a definicija programiranja procesa vježbanja kao metodološko-metodičkog postupka utvrđivanja i primjene energetsko-informatičkih ulaza i kontrole njihovih izlaza uz poznato stanje subjekta i prethodno definirane ciljeve (Mraković, 1987) čini proces programiranja integriran $\mathrm{s}$ procesom individualizacije (Prskalo, Babin, 2010). Findak i Neljak naglašavaju stvaralaštvo kao individualni čin, a proces vježbanja mora biti primjeren svakome subjektu, jer takva orijentacija je uvjet kvalitete u svim primijenjenim područjima kineziologije (Findak, Neljak, 2010). Provjera antropoloških obilježja kao temeljnog uvjeta programiranja individualnog rada u predmetu Tjelesna i zdravstvena kultura „po mjeri“ djeteta, učenika i studenta je, prema podacima Prskala i Babina

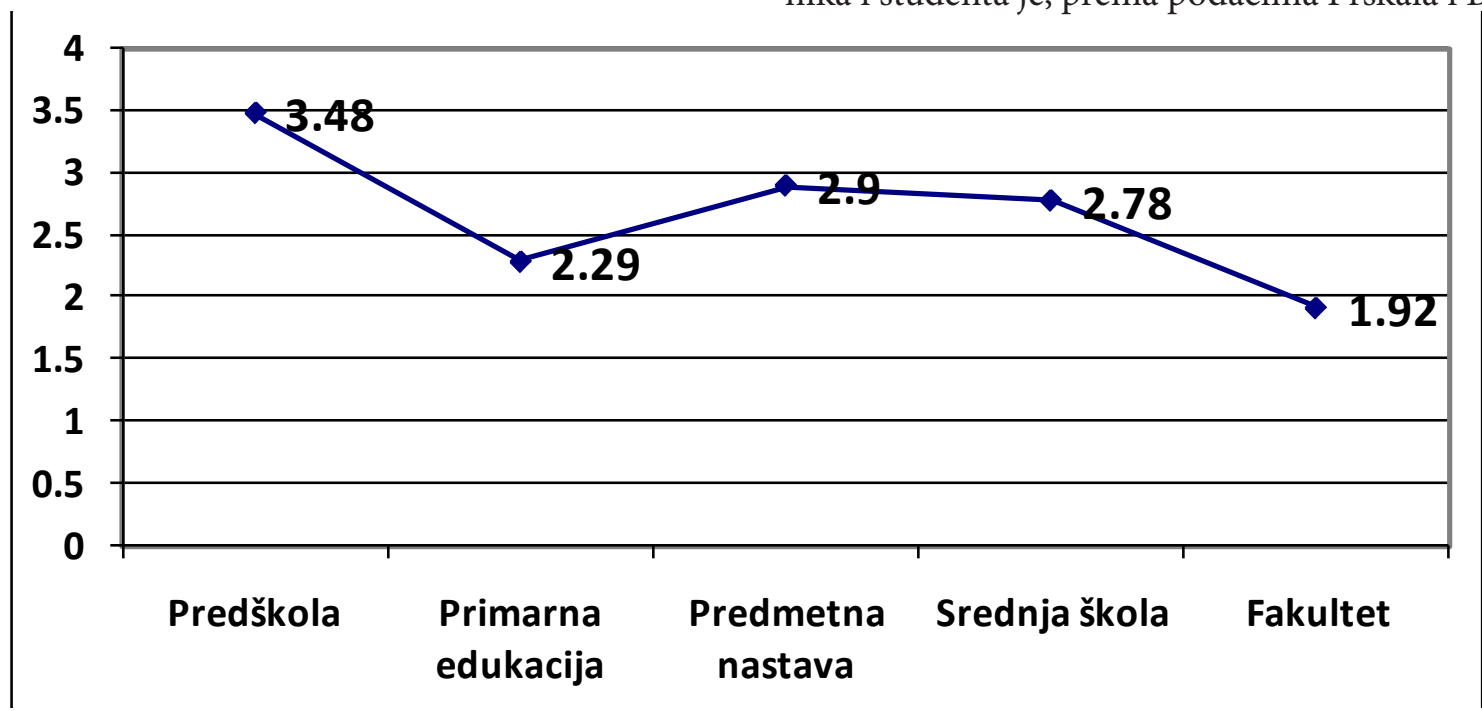

Slika 7. Broj provjera antropoloških obilježja u prethodnoj godini po odgojno-obrazovnim razinama (Prskalo, Babin, 2010: 26). 
(Prskalo, Babin, 2010), prihvatljiva, osim na sveučilišnoj razini, gdje se prema odgovorima anketiranih nastavnika nije provodila niti dva puta godišnje.

Provjeravanje prije početka programiranja rada ne provodi čak $53 \%$ nastavnika na sveučilišnoj razini (Prskalo, Babin, 2010). „Perspektiva individualizacije rada u kineziološkoj edukaciji temelji se na znanstveno utemeljenoj dijagnostici, poštivanju individualiteta kroz primjenu složenijih metodičkih organizacijskih oblika rada i svrstavanjem subjekata $\mathrm{u}$ homogenizirane skupine, kontinuiranu edukaciju i primjeren stručni nadzor te osiguranje materijalnih potreba obrazovnih institucija uz stalnu znanstvenu prizmu svih upravljanih procesa" (Prskalo, Babin, 2010: 34).

\section{Zaključak}

Imajući u vidu značaj kretanja, a posebice kinezioloških aktivnosti koje su definirane ciljem svih ostalih oblika tjelesnih aktivnosti, značaj i odgovornost kineziološke edukacije je svakim danom sve veći, a poglavito zbog suvremenih promjenama životnih uvjeta. Naime, optimalni odgovori društva na svakodnevne promjene životnih uvjeta treba da se, prije svega, prenesu putem najodgovornijeg primijenjenog područja za stanje ukupne populacije, a to je edukacija. Ta optimizacija bi se morala prije svega odnositi na učestalu primjenu svih organizacijskih oblika rada u tjelesnom i zdravstvenom odgojno-obrazovnom području, s posebnim naglaskom na temeljnom organizacijskom obliku rada satu tjelesne i zdravstvene kulture. Primjena odgovarajućih modaliteta rada, primjerenih značajkama djece, učenika i studenata, uz primjenu suvremene nastavne tehnologije doprinijet će individualizaciji rada, a tako primjeren rad subjektu kao epicentru edukacije značajno doprinijeti kvaliteti rada u ovom području.

\section{Literatura}

- Bavčević, T., Babin, J. \& Prskalo, I. (2006). Complex group organizational forms - an optimizing factor in Physical education instruction. Kinesiology. 38 (1), 28-39.

- Ćorić, T., Miler, A. (2013). Izvješće o umrlim osobama u Hrvatskoj u 2012. godini. Zagreb: Hrvatski zavod za javno zdravstvo.

- Findak, V. (1992). Metodika tjelesne i zdravstvene kulture. Zagreb: Školska knjiga.

- Findak, V. (1995). Metodika tjelesne i zdravstvene kulture u predškolskom odgoju. Zagreb: Školska knjiga.

- Findak, V. (1999). Metodika tjelesne i zdravstvene kulture. Zagreb: Školska knjiga.

- Findak, V. (2001.). Kineziološki pogledi na uspješnu školu. U: Zbornik radova Uspješna škola (23-31). Zagreb: Hrvatski pedagoško-književni zbor.

- Findak, V., Mraković, M., Prskalo, I. (2003). Kineziološki vidici uloge učitelja u razvoju djeteta i škole. U: Prskalo, I. i Vučak, S. (ur.) Zbornik radova. Treći dani Mate Demarina: Učitelj - učenik - škola (36-43). Petrinja: Visoka učiteljska škola Petrinja; Hrvatski pedagoško-književni zbor.

- Findak, V., Neljak, B. (2006). Kvaliteta rada u područjima edukacije, sporta i sportske rekreacije. U: Findak, V. (ur.). Zbornik radova „15. ljetna škola kineziologa Republike Hrvatske“(16-23). Rovinj: Hrvatski kineziološki savez.

- Findak, V., Neljak, B. (2010). Individualizacija rada u područjima edukacije, sporta i sportske rekreacije. U: Findak, V. (ur). Zbornik radova „19. ljetna škola kineziologa Republike Hrvatske“ (14-20). Poreč: Hrvatski kineziološki savez. 
- Findak, V. \& Prskalo, I. (2011). Kinesiological prevention - an important factor in the integrative power of kinesiology. In: Milanović, D. \& Sporiš, G. (Eds.) 6th International Scientific Conference on Kinesiology Integrative power of kinesiology (223-225). Opatija: Faculty of kinesiology, University of Zagreb.

- Findak, V., Prskalo, I., Babin, J. (2011). Sat tjelesne i zdravstvene kulture u primarnoj edukaciji. Zagreb: Učiteljski fakultet Sveučilišta u Zagrebu.

- Findak, V., Prskalo, I. \& Pejčić, A. (2003). Additional exercise as an efficiency factor in physical education lessons. Kinesiology. 35 (2), 143-154.

- Findak, V., Prskalo, I., Ružić, E. \& Šerbetar, I. (2005). Kinesiology science and profession in functionof quality school. In: Milanović, D. \& Prot, F. (Eds.) 4. Internacional scientific conference on kinesiology (76-77). Opatija: Faculty of kinesiology, University of Zagreb.

- Flynn, M. A. T., McNeil, D. A., Maloff, B., Mutsingwa, D., Wu, M., Ford, C. \& Tough, S. C. (2006). Reducing obesity and related chronic disease risk in children and youth: a synthesis of evidence with „best practice“ recommendations. Obesity Reviews. 7 (Suppl. 1), 7-66.

- Hardman, K. (2000). Športna vzgoja in šolski šport in Evropi. U: Zbornik radova Razvojne smjernice športne vzgoje (9-23). Nova Gorica: Zveza društev športnih pedagogov Slovenije.

- Horgan, G. (2005). Healthier lifestyles series: 1. Exercise for children. Journal of Family Health Care. 15 (1), 15-7.

- Horst, K. V. D., Paw, M. J. C. A., Twisk, J. W. R. \& Van Mechelen, W. (2007). A brief review on correlates of physical activity and sedentariness in youth. Med Sci Sports Exerc. 39 (8), 1241-1250.

- Jensen, E. (2003.). Super-nastava. Zagreb: Educa.

- Jurak, G., Prskalo, I., Babin, J. (2015). Uloga suvremenih informacijskih komunikacijskih tehnologija u kvaliteti tjelesne i zdravstvene kulture. U: Findak, V. (ur.). Zbornik radova „22. ljetne škola kineziologa Republike Hrvatske“ - Primjena i utjecaj novih tehnologija na kvalitetu rada u područjima edukacije, sporta, sportske rekreacije i kineziterapije (18-33). Poreč: Hrvatski kineziološki savez.

- Ministarstvo znanosti, obrazovanja i športa (2011). Nacionalni okvirni kurikulum za predškolski odgoj $i$ obrazovanje te opće obvezno i srednjoškolsko obrazovanje. Zagreb: Ministarstvo znanosti, obrazovanja i športa.

- Mišigoj-Duraković, M., Duraković, Z., Ružić, L., Findak, V., Delija K. (2003). Čimbenici opasnosti za razvoj bolesti srca i krvožilja u kineziologa. U: Findak, V. (ur.). Zbornik radova „12. ljetne škole kineziologa Republike Hrvatske" - Metode rada u području edukacije, sporta i sportske rekreacije (42-47). Rovinj: Hrvatski kineziološki savez.

- Prskalo, I. (2007). Kineziološki sadržaji i slobodno vrijeme učenica i učenika mlađe školske dobi. Odgojne znanosti. 9, 2 (14), 319-331.

- Prskalo, I. (2015). Kinesiology of free time. Croatian Journal of Education. 17 (1), 219-228.

- Prskalo, I., Babin, J. (2006). Kvaliteta rada u području edukacije. U: Findak, V. (ur.). Zbornik radova „15. ljetna škola kineziologa Republike Hrvatske"(26-34). Rovinj: Hrvatski kineziološki savez.

- Prskalo, I., Babin, J. (2008). Stanje i perspektiva razvoja u području edukacije. U: Neljak, B. (ur.). Zbornik radova „17. ljetna škola kineziologa Republike Hrvatske“ (30-41). Rovinj: Hrvatski kineziološki savez.

- Prskalo, I., Babin, J. (2010). Individualizacija rada u području edukacije U: Findak, V. (ur.). Zbornik radova „19. ljetna škola kineziologa Republike Hrvatske“ (22-35). Poreč: Hrvatski kineziološki savez. 
- Prskalo, I., Findak, V., Babin, J. (2003). Uspješnost metoda učenja u nastavi tjelesne i zdravstvene kulture mlađe školske dobi. Napredak. 144 (4) 486-493.

- Prskalo, I., Sporiš, G. (2016). Kineziologija. Zagreb: Školska knjiga; Učiteljski fakultet Sveučilišta u Zagrebu; Kineziološki fakultet Sveučilišta u Zagrebu.

- Rosić, V. (1999). Nastavnik - čimbenik kvalitete odgoja i obrazovanja: U: Rosić, V. (ur.). Zbornik radova. Drugi međunarodni znanstveni kolokvij - Nastavnik čimbenik kvalitete u odgoju i obrazovanju (1-10). Rijeka: Filozofski fakultet Sveučilišta u Rijeci.

- Vuori, I. (2004). Physical inactivity is a cause and physical activity is a remedy for major public health problems. Kinesiology. 36 (2), 123-153.

- Warburton, D. E., Nicol, C. W. \& Bredin, S. S. (2006). Health benefits of physical activity: the evidence. CMAJ. 174 (6), 801-809.

\begin{abstract}
Summary
Change is a significant characteristic of the times we live in. As changes are reflected on the entire population, the response to them should be appropriate. The positive influence of physical exercise on anthropological status can hardly be compared to any other human activity, and the link between physical exercise, motor and functional abilities on one hand, and physical health and the quality of living, on the other, should not be ignored. Applied research and its consistent implementation in practice are the prerequisites for achieving quality in this extremely important area. An overview of experiences that contribute to the quality of kinesiology education as a prerequisite for survival shows that special attention should be paid to the status of anthropological features, as an essential precondition for individualisation, but also to the consequences of the individual approach to its optimisation. Organisational forms of work in the physical education and health care areas, as well as the proper application of these forms in line with the paradigm that has been effective in practice many times, are also important factors of individualisation and the quality of work in kinesiology education. Bearing this in mind, the response of society to an increasing number of challenges of modern civilisation must be aligned with the outreach of the science of kinesiology and kinesiological methodology as its applied discipline. Given the "stake", only the best answer is a good enough answer.

Keywords: quality, kinesiology education, anthropological characteristics, physical education class, individualisation.
\end{abstract}

